\title{
Identification of indigenous people in Aotearoa-New Zealand-Ngā mata o taku whenua $^{1}$
}

\author{
John Waldon \\ Faculty of Public Health and Community Medicine, University of New South Wales, Sydney, Australia \\ E-mail: J.A.Waldon@unsw.edu.au
}

\begin{abstract}
Establishing meaningful ethnicity classification standards and rules is part of the solution to producing improved health measurement for Indigenous people. The remaining effort should be devoted to establishing a statistical framework and protocols that enables the inclusion of Indigenous cultures and languages into the development and operationalisation of measures and protocols for collecting and analysing data. This process is underway in Aotearoa-New Zealand to develop administrative data and institute new statistical frameworks that better reflect Indigenous values and society. Health data can be linked to administrative data to fill gaps in our knowledge and understanding of Indigenous health measurement.
\end{abstract}

Keywords: Indigenous health measurement, Aotearoa, New Zealand, Indigenous well-being, Māori, well-being, hauora, health, hinengaro, bias, undercount

\section{Purpose and overview}

Accurate and comprehensive health information regarding Māori, the Indigenous people of AotearoaNew Zealand is limited. This makes it difficult to illustrate changes in health for Māori. Understanding why consistent health statistics and measures for Māori are not readily available is multifaceted and a challenge to the National Office of Statistics (NOS), Statistics New Zealand (Statistics NZ) and those who partner with Māori to develop statistical products. In this paper, collection of ethnicity data is presented and interpreted from an Indigenous perspective regarding the recent development of a new social survey and the use of the census ethnicity question linked to administrative data. The later will also illustrate a potential hazard that has implication for understanding the statistical challenge of small populations in Aotearoa-New Zealand. When data or measures do not exist, that will be pointed out.

\footnotetext{
${ }^{1}$ The faces of the place of my birth, my family, my people, my identity.
}

In order to provide appropriate and responsive healthcare, knowing ethnicity of Indigenous people provides for a comprehensive and more complete understanding of their needs. Analyses undertaken by non-Indigenous people not familiar with cultural issues may be open to mis-interpretation. Professor Mason Durie advised,

No single measure can give an accurate indication of the state of Māori health. Because health encompasses at least the dimensions of wairua, hinengaro, tinana, and whānau, the indices normally used are limited and tend to reflect only one dimension and, even then, focus on sickness and illness rather than the wider view of health. Furthermore, an assessment of contemporary Māori health status requires more precise definition of the terms 'Māori' and 'health'. In the past neither have been described in a consistent manner, so that accurate comparisons of past to present, or Māori and non-Māori , have been hindered by different understandings and definitions [1, p. 125]. 
It follows therefore, that a comprehensive understanding of the well-being of Māori will be informed by an accurate determination of ethnicity and decent, and that wisely interpreted statistics would include recognised Indigenous perspectives.

\subsection{The arrival of Māori}

Delivering the Millenium Lecture at Massey University [2], Professor Mason Durie, referred to the research of Rosalind Murray-McIntosh and colleagues. Professor Mason Durie said,

none of us really know for sure what life was like in New Zealand in the year 1000. But very elegant DNA studies, from Massey University no less, seem to confirm that a significant colony of Māori settlers was firmly established some 800 or so years ago.

Contrary to the 'Great Fleet' theory of the settlement of Aotearoa-New Zealand advocated by S. Percy Smith [3]. Murray-McIntosh and colleagues offered a new explanation that is consistent with Māori oral traditions of the deliberate exploration and migration of the Pacific ocean, to and from Aotearoa-New Zealand [4]. Polynesian settlement of Aotearoa-New Zealand was made well before the arrival Europeans in the late 17 th century, the first census was a collection of sub-population data in 1851, counting the newly arrived European immigrants in order to establish electoral rolls [5] to form government in 1853 [6]. Electoral representation and franchise use race-based electoral rules and regulations from the census, determining who could vote and mandate the Parliament.

In 1998, Māori Advisor to Statistics NZ, Cyril Mako in his keynote address to the Māori Development Conference, Te Oru Rangahau said,

Key rigidities have been the inflexibility of statistical information gathering methods and systems, and the very high costs of identifying the members of small populations. The language and concepts of statistical communication are invariably English, and they often fail to recognise differences in how Māori think or relate to others. It has taken one-third of a century of computerisation to enable sufficient flexibility of information management and access across government to make the study of small populations economically viable [7, p. 40].
In 2016, Statistics NZ published a literature review of the way contemporary Māori groupings are organised and understood based on the research undertaken by Maka Angyalova [8]. This analysis of contemporary Māori views of Māori social organisation and identity extended those expressed by John Rangihau [9-11] and Ranginui Walker [12,13]. The report provided helpful descriptions that defined contemporary Māori social groups for the reader unfamiliar with Māori society.

Whenua, an important aspect of identity can refer to the placenta, birthplace and land, all important aspects of te ao Māori (Māori world view) [14,15]. Māori views of health and well-being take a broad or wholistic view and consider the inter-relationship of physical, mental, spiritual and family when considering the individual. Professor Mason Durie said of the individual as an independent 'in one's own right' for Māori is an unhealthy state, therefore the sole focus on the individual "within the mental health field have little credibility in Māori eyes" [16, p. 485] rather than considering the family and its role in a person's identity and the family's contribution to a person's health. Therefore, it is a healthy state to be identified with a group such as whānau, the desire to identify as Māori with the knowledge of Māori descent.

While the management of the census and the data generated are within the ambit of Statistics NZ, and the recent migration to internet-based census, the definitions that underpinned the census variables and aid in their interpretation reflect contemporary society aligned with Māori society. Thus, while statistics relevant to Māori are hard to come by, structural approaches offer the opportunity to integrate the cultural knowledge and cultural perspective necessary to provide an analysis that fits with the expectations of Māori.

\section{History and culture}

Polynesian settlement of Aotearoa-New Zealand was undertaken [17] during a series of purposive expeditions by Polynesian explorers to whom many modern Māori trace their ancestry [18]. Analysis of volcanic ash provided soil scientists David Lowe [19] with an indication of burning and deforestation that matched settlement dates of c. 1250-1300 AD from the archaeological remains found at the ancient Wairau Bar. Permanent gardens and settlements were developed to sustain organized large-scale gardening [17,20,21], devel- 
oping Māori plaggen soils, soils agriculturally modified to a depth of 20 to 50 centimeters to promote plant growth [22]. This suggested an organised and well settled Indigenous population prior to the introduction of nineteenth century European agriculture.

The 1851 census enumerated the European population and facilitated voting a year later, with race systematically collected from 1916, classifying Māori, European and 'race aliens' following the Māori Representation Act 1867 [23] which granted Māori separate representation [24]. The admix of Māori and European was classified either by degree of blood (more than half blood a person was classified to belong to that race group, or as European if living 'in a European fashion'). The Land Wars [25] following the installation of a colonial Government accelerated the alienation of New Zealand's land from Māori to Pākehā (European) ownership, and most Māori subsequently became impoverished [26].

From 1858, Māori participated in the censuses regularly and census information was supplemented with medical, land transfer, and education records collected by government departments and published in the Appendices to the Journal of the House of Representatives each year [27]. From 1926 to 1971, Māori were counted using the definition of declaring more than half Māori blood [28]. Following the Māori Affairs Amendment Act 1974 [29] a Māori person was defined as a person of Māori ancestry necessitating changes to the census as described by Cormack and Robson [30]. These changes were to accommodate the classification of individuals who identify with more than one ethnic group under new recommended practice for coding and inputting multiple ethnicities in health statistics [30,31].

A challenge for policy makers is matching those identified as Māori with those who will benefit from this distinction. Birth and death notifications rely on a statutory definitions based on descent, while census and health statistics use self-identified ethnic affiliation, and the difference Kukutai [32] argues is related to those who either do not have Māori descent or do not culturally identify as Māori. Māori may not be a key factor in the identity of those who identify as Māori, but who are not of Māori descent, as well as those who are of Māori descent, but do not identify as themselves as Māori.

Ethnic self-identification in health is now governed by a statistical standard and protocols for collecting, recording and outputting of ethnicity data, Health Information Standards Organisation's (HISO) HISO
10001:2017 Ethnicity Data Protocols, overseen by Statistics NZ [33].

\subsection{The Treaty of Waitangi and the Waitangi Tribunal}

After much negotiation the Treaty of Waitangi (the Treaty) was entered in to by the Chiefs of New Zealand and the British Crown on the 6th of February 1840 [34]. Both parties agreed to respect the rights of Māori to own their lands and treasures in exchange for the right of the Crown to purchase land and to have governorship over the country. The principles and agreements put in place with the signing of the Treaty of Waitangi were subsequently breached many times and became the reason for many approaches to Government for redress. The Government of the day addressed few of the Treaty breaches, bringing with that a loss of confidence in the Treaty and the physical deterioration of the Treaty document itself.

New Zealand established the Waitangi Tribunal, a standing commission of inquiry to hear claims from Māori regarding breaches of the Treaty [1,35] and make recommendations to the government regarding breaches of the promises made in the Treaty. Established by the Treaty of Waitangi Act 1975, the Waitangi Tribunal hears claims dating back to 6th February 1840 , the date of the signing of the Treaty of Waitangi. Forty years later, in 2015, it has reported on 1028 of 2501 registered claims. An example is the Ngāi Tahu Claims which were the largest in terms of land area. Ngāi Tahu pursued claims against the Crown for unfair purchase practices and of breaches of the deeds of purchase. On 26 August 1986, the first of several claims was submitted to the Waitangi Tribunal by Henare Rakiihia Tau and the Ngāi Tahu Māori Trust Board (Wai 27). The Waitangi Tribunal investigated the claims and on February 1st, 1991, presented its first of several reports. The recommendations of the Waitangi Tribunal were legislatively enabled by the Ngāi Tahu Claims Settlement Act 1998. Once the Waitangi Tribunal has reported, the Office of Treaty Settlements (Ministry of Justice) negotiates, on behalf of the Government, with the claimant and it holds approximately \$232.241 million in Government owned surplus land assets to offset for some of the land lost in breach of the Treaty. 


\section{Census}

On the 6th of March, 2018 the census was offered using a 'digital first strategy' signaled in 2015, when Statistics NZ was directed to actively work towards an administrative data census through a range of activities [36]. The 2018 Census was delivered through online participation with postal reminders and house hold visits to those who had not completed a census form. More time was allocated to the follow up when initial calculations showed that only 90 percent of individuals had at least partially completed the census compared with 94.5 percent for the 2013 census.

Following the census imputation is used to cover missing information. Unit imputation adds to the census count in cases where there is sufficient evidence that a person exists, or a dwelling is occupied. Where a census form has been provided, item imputation or donor imputation adds information for missing values. This is standard procedure for all respondents.

In order to capture measures of Indigenous identity the census questions include ethnic self-identification and Māori descent. Using the same basic questions from the 2013 census to determine individual ethnicity and descent, Statistics NZ asked what ethnic group(s) all individuals belong to, and if they were descended from a Māori. Those of Māori descent then indicated the Iwi (tribe or tribes) they identify with and the rohe (Iwi area) [37]. Should an attempt be made to prioritise Iwi affiliation, it would introduce another bias if there is based on a misunderstanding of the nature of Iwi affiliation. Statistics NZ also offers a service for deriving Iwi-based statistics and have established an Iwi Statistical Standard and resources to support the standard [38]. Prior to this, there was no structured approach to collecting this data for research.

The number of ethnic groupings recognised in administrative data is influenced by the size of the group and this in turn affects the way ethnicity is reported. The two main methods used in the health sector when reporting multiple ethnicities are prioritisation and reporting a small number of the main ethnic groups [30, p. 34], Bias, that may appear in ethnicity reporting, occurs for some populations because members are 'lost' when they are prioritised into another group as observed for Pacific and Asian ethnicities by Tan et al. [39]. The implication for Māori was that an individual identified as Māori and Pacific or Asian was prioritised as Māori.

\subsection{Surveys for Māori}

The development of surveys of Māori groups by Māori were undertaken including the Māori Women's Welfare League in the 1980s with Rapuora [40] followed in the 1990 s by Massey University with Te Hoe Nuku Roa [7,41-43] and Oranga Kaumātua [44]. The purpose of these studies was to provide specific information about Māori not collected in administrative data or by the census. Both had the support of a wide range of academics, Statistics NZ's Chief Statistician, Len Cook, and broke new ground in the participation of Māori communities.

Breaking new ground in 1987, was the Government's support for a national Māori language survey followed te reo Māori (the Māori language) being recognised as an official language of Aotearoa-New Zealand. The effect of this was to characterise the population's use of te reo Māori and to protect its use as an official language [45]. Presently Statistics NZ is analyzing their recently concluded a consultation period for measuring well-being tailored to AotearoaNew Zealand to assist with the routine collection of data more relevant to the well-being of Māori [46].

\subsection{Hauora-Māori standards of health}

Following advocacy to improve the quality and utility of statistics for Māori, Statistics NZ responded to initiatives from the Medical Research Council [47] and the University of Otago [30,48-51] to improve the quality of Māori data and measures. Initiated by Professor Eru Pōmare, a series of studies published using available data showed that Māori were not only disadvantaged in many areas of health, the data and measures used to support this were sub-standard. The establishment of the research group at the University of Otago in the 1980s, now known as Te Rōpū Rangahau Hauora-a-Eru Pōmare, was a strategic investment in the development of better standards for describing and quantifying Māori health. The Census Mortality Study [52-55] used anonymous probabilistic linkage between census and mortality records and demonstrated a growing gap in life expectancy between Māori and non-Māori throughout the 1980s and early 1990s. After correcting for undercount of Māori ethnicity in mortality records, they found that the gap in life expectancy at birth of six to seven years had grown to eight to nine years for Māori when compared with non-Māori. This did not hold by socioeconomic status with the gaps remaining the same between low- 
and high-income groups. The gap grew for those aged 25-44 years and decreased for the 60-77 year old group [55]. In the later report, differences in socioeconomic status between Māori and non-Māori accounted for about one-third of the all-cause mortality gap and was confirmed in the fourth report [56]. In the fourth report, ethnicity and socioeconomic status were shown separately and the period extended to 2004 [57]. The authors concluded that the gap had "stabilised, and absolute inequalities (mortality rate differences) may have begun to decline - a turnaround of major importance if it can be sustained" [57, p. 118]. They also found that after adjusting for numeratordenominator bias, mortality that Pacific adult mortality was approaching that of Māori.

The data preparation required for these reports often necessitated the investment of a great deal of time and expertise to undertake detailed data editing and data linkage to improve the quality of census and administrative data. The lack of appropriate data of sufficient quality and consistent standard also came with opportunity costs. Cormack and Harris [49] observed that the time and cost required to make the necessary improvements of data could be directed to interventions. A clear benefit of the work of these two research teams at the University of Otago was the development and implementation of ethnicity standards in 2005 [58] and the development of HISO 10001 Ethnicity Data Protocols [33], appear to have addressed the undercount due to ethnicity misclassification once evident in hospital discharge data, mortality data and therefore life expectancy as reported by Blakely et al. in 2002 [59, p. 149].

\subsection{Te Kupenga}

Te Kupenga is a report of research commissioned by the Ministry of Māori Development and undertaken by Statistics NZ. It was the very first national survey of Māori outside the census. It was undertaken in 2013 [60] and repeated in 2018. The first release of information from Te Kupenga 2013 provided overview statistics on four areas of Māori cultural well-being; wairuatanga (spirituality), tikanga (Māori customs and practices), te reo Māori (the Māori language), and whanaungatanga (social connectedness). Te Kupenga data is available as a Confidentialised Unit Record File (CURF), comprised of unit record data and a data dictionary. The Customised Data Services Team (Statistics NZ) can be contacted for assistance in extracting the required data from Te Kupenga, or if the required data is not available in the CURF or data tables.

\subsection{He Arotahi Tatauranga}

In 2014, Statistics NZ released He Arotahi Tatauranga [61], a statistical framework using Māori wellbeing. It was development to meet Māori information needs. He Arotahi Tatauranga provides a framework with which people can gather measures and data of good quality about Māori. This information can be used to monitor the effects of government policies and programmes. The framework was developed to inform those investigating Māori development and well-being in a comprehensive and consistent manner. The six Māori development dimensions which unfold to reveal eighteen topics ( ' $y$ ' axis, including Māori language and Māori land) of significant interest to Māori development. Complementing the development topics are six well-being dimensions (' $x$ ' axis, including social capability and environmental sustainability). The eighteen development topics and six well-being dimensions form a framework and were developed to enable linkages between measures across different dimensions of a topic, and so that the measures would be meaningful and comparable across regions and different subpopulations. For example one could analyse the use of Māori language by cross tabulating it with social capability to characterise the use of Māori language and the quality of social interactions. The remaining Māori development topics and well-being dimensions are well defined, correspond to important aspects of well-being using familiar terms to encourage their use across administrative and census data and measures.

Building on work undertaken over the past years, He Arotahi Tatauranga provides a set of measures well supported by rationale and clear definitions. In the rationale for He Arotahi Tatauranga, each topic, for example Māori language, is described in multiple contexts. The topics and dimensions are well defined and make clear and appropriate use of te reo Māori (the Māori language). In order to make best use of He Arotahi Tatauranga, prepared questions are provided for many of the overlapping areas of interest.

From 18 February 2019, Statistics NZ will host a specific webpage, working with Iwi to enable greater access with data and the insights data can provide [62]. This page will show links for the latest information releases, publications, downloadable CSV data files and Statistics NZ data tools about ethnicity. An important aspect of the use of these statistics outside health measurement is a searchable library that will give further information on the use of variables (such as ethnicity) and applicable standards across all of the Gov- 
ernment's statistical activities. This library is called Ariā and a link is available on the Statistics NZ web site [63].

In concluding this section, it is generally agreed that self-completed ethnicity question is the best method for collecting ethnicity for population [33] and administrative data [48], and this is supported by AotearoaNew Zealand's Indigenous data sovereignty collective Te Mana Raraunga [64]. Statistics NZ has developed resources that have topics and dimensions that reflect the well-being issues relevant to Māori. Statistics reporting on the status of Māori was once circumscribed by imposed definitions of who Māori are $[8,9,11,12,32,65]$, resulting in misclassification and undercount of Māori giving rise to numerator and denominator bias. Some of the bias was addressed by reassignment of ethnicity or adjustment [49]. The imposition of definitions on Māori overlooked an essential right to be informed by these statistics. The development of the ethnicity data protocol by the Ministry of Health in collaboration with Statistics NZ, and He Arotahi Tatauranga framework, and the searchable library of variables in Ariā are new ways of consistently collecting and understanding Māori health and wellbeing from multiple perspectives that are philosophically linked to both Māori culture and supported by the appropriate use of te reo Māori, two important facets to bringing Māori data into a framework to engage with Māori aspirations are interpretation and design.

The settlement of Treaty claims between the Crown and Māori has provided the opportunity for Māori to develop Iwi assets and distribute the dividends to their members. Rather than service many independent Iwi registers, the Tūhono Trust (Tūhono) [66], oversees a series of Iwi registers that record the beneficiaries of Treaty settlements using a central web service that provides direct and automated updates of member's information to the database systems operated by Iwi, automatically updating an Iwi's database and capturing new registrations, the Tūhono web service ensures the network is technologically up to date, incorporating the same levels of security used by banks.

Tūhono was established under the Electoral Act 1993 to assist Māori to register with their Iwi and other Māori entities. Once a person is registered, Tūhono links to the Electoral Enrolment Centre database, which is updated monthly by the Ministry of Transport, NZ Transport Agency, New Zealand Post and Department of Internal Affairs, notifies Iwi of changes of address and updates when a person dies. A person's Iwi membership is validated by each Iwi's traditional advisors.

\subsection{Statistical measures and indicators}

Margaret Whitehead observed that systematic differences between different socio-economic groups in society are inequalities [67], and that a just and fair society collects the relevant data. Whitehead noted that,

"inequalities" in the British context - and increasingly also across Europe - carries the same connotations of unfairness and injustice as the term "inequities" [67, p. 473].

The logical reasoning that connects intervention programme inputs to intended outcomes assumes not only a causal pathway but also consistency of information, the former following accepted knowledge of the link between the intervention and the impact or outcomes, and that this can be quantified or described. It is reasonable to assume that improvement would follow affirmative actions and legislative protection recommended in Hauora: Māori Standards of Health IV [68, p. 3], and as reasoned by Whitehead [67], the data related to the actions and interventions that reduced inequalities would be collected.

While having a relatively young population distribution, Māori have lower levels of income, and higher rates poverty when compared with their non-Māori peers. Efforts have been made to ensure that consistent and accurate data is available to inform at a community level, and based on individuals as much as possible, will achieve Government-wide consistency of definition and concepts as outlined by Ariā [63]. Statistics NZ will begin a new service to inform Iwi [61] in early 2019 that is available to be interrogated from Māori perspectives, with the potential to measure efficiently changes in inequality. However after reviewing on-line admin forms, Reid et al. observed the same standards and protocols are not evident across departments of government [80].

For example the Ministry of Education uses ethnicity data to survey participation, retention and achievement by ethnicity to support policies that target equity funding, such as funding used to reduce educational disparities between different groups, reduce barriers to participation for groups underrepresented in education, and to support education services to raise their children's level of educational achievement. The Ministry of Education advises schools to use Statistics NZ 's ethnicity question but does not specifying the 2006 census ethnicity questionnaire format. School enrolment forms enable students to identify with up to three ethnicities and these are recoded by schools when 
students are enrolled. Schools are advised by Ministry of Education to report a student by one ethnic group in their roll return tables, using the prioritization strategy recommended by Statistics NZ [69].

The ethnicity question is absent from many electronic forms offered to people applying for social support or enrolling their children in school. Where it is found it varied from the format recommended in the 2006 census. Also lacking is a standard Māori descent question. The challenge for the education sector is that the enrolment forms used to record the details of the children and their parents do not always record ethnicity and decent and varying from school to school. When ethnicity is recorded, it is often in a nonstandard format to the 2006 census ethnicity question. Suggested guidelines to follow for recording ethnicity are nonexistent and there appears to be no checking process.

\section{National portrait}

The overall national portrait of the Māori population was most recently updated in the 2018 Census and the Māori population is distributed between Aotearoa-New Zealand and Australia. In 2011, Kukutai and Pawar [70] estimated the Māori population living in Australia to be 128,430 when the Māori population in New Zealand was estimated to be 675,500 [71].

Statistics New Zealand estimates the Māori population to be 744,800 as of the 30th of June 2018 [71], comprising 363,000 males and 381,000 females, with a median age of 23.1 and 26.1 years respectively. The Māori population is growing at an estimated 1.4 percent annually.

From the 2013 census, Māori (non-Māori) had a median income of $\$ 22,500$ (\$28,500), were comprised 14.1 (85.9) percent of population, 66.7 (79.1) percent had formal educational qualifications, and the fertility rate was 2.5 (1.9) births per woman. In the education system 19.2 percent of Māori teachers taught in Māori medium education, and Māori teachers represent 9.8 percent of all teaching staff. In the area of health, the infant mortality rate is 6.96 (3.95), the Sudden Infant Death in infancy rate is $2.14(0.48)$.

Of the children placed under the guardianship of the Chief Executive of the Children's Ministry, in 2017, of the 5,048 children in guardianship, 69.7 percent were Māori [72].

Māori are incarcerated at higher rates than their non-Māori peers. As of June 2012, Māori (non-Māori) make up 58 (31) percent of the female prison population, and 51 (33) percent of the male prison population. The Ministry of Justice are aware of systematic biasses in their reporting. The Ministry of Justice attributes bias to an under-count due to time from reporting a crime to when a crime is resolved, and a lack of data on victims and historic offences.

The government departments undertake satisfaction research and report against a Common Measurements Tool (CMT), a standardised set of questions, the CMT is part of wider State Services Commission research on public service delivery [73]. The New Zealand Police's Citizen's Satisfaction Survey reports against a CMT that included a Māori booster sample. The CMT used the same ethnicity categories as the census, recording multiple responses but not place of birth for NZ European or Māori [74] descent or employ the same format as the Statistics NZ census ethnicity and descent questions.

\section{Subpopulations}

Within the official data collected by Government and many non-Government agencies are data that are used to quantify the status of Māori. Although comprehensive data are almost nonexistent these include Māori in the criminal justice system, foster system, and the health sector. Māori tend to be negatively over-represented in these groups. Their experience and movement between these subpopulations (e.g. school to prison pipeline) directly affect the health and well-being of Māori and their communities. The impact of complex jurisdictional issues across the different communities of need has focused the attention of the Government most recently due to the recent inquiry into mental health $[75, \mathrm{p} .13]$ where a whole-of-government approach is recommended. The inquiry was informed by data from the 1997 National Mental Health Plan [76] and Te Rau Hinengaro [77], the national mental health survey, published in 2006. The data shortcomings were identified in the National Mental Health Plan that would compromise efforts to achieve under the hedings of cultural responsiveness (p. 18) and the planning and monitoring of services (p. 21), were to be addressed by collecting data according the data protocols. The plan identified the very nature of the health sector as 'perhaps the biggest challenge to developing a culturally competent mental health information system' [76, p. 6]. 
Table 1

\begin{tabular}{|c|c|c|c|c|c|c|}
\hline \multirow[b]{2}{*}{ Region } & \multicolumn{3}{|c|}{$\begin{array}{c}\text { Scenario one } \\
100 \% \text { ethnicity completeness - } \\
\text { consistent across the regions }\end{array}$} & \multicolumn{3}{|c|}{$\begin{array}{c}\text { Scenario two } \\
\text { Partial ethnicity completeness - } \\
\text { inconsistent across the regions }\end{array}$} \\
\hline & Metropolitan (100\%) & Urban $(100 \%)$ & Rural (100\%) & Metropolitan (65\%) & Urban $(80 \%)$ & Rural $(95 \%)$ \\
\hline $\begin{array}{l}\text { Recorded Indigenous } \\
\text { enrolments }\end{array}$ & 2250 & 2250 & 2250 & 1463 & 1800 & 2138 \\
\hline Population & 15000 & 15000 & 15000 & 15000 & 15000 & 15000 \\
\hline Apparent & 15 & 15 & 15 & 9.8 & 12.0 & 14.3 \\
\hline \multicolumn{7}{|l|}{ Enrolment (1) } \\
\hline Enrolment ratio (2) & 1.0 & 1.0 & 1.0 & 1.0 & 1.23 & 1.46 \\
\hline
\end{tabular}

Notes: (1) Completeness refers to the proportion of enrolments that are correctly classified. (2) Crude rate per 1,000 population. (3) With metropolitan as the reference for each scenario.

\subsection{Government Integrated Data Infrastructure}

The Integrated Data Infrastructure (IDI) is a research database that holds de-identified microdata about people and households, with encrypted identity numbers. The IDI is primarily based on the linkage of administrative data and allows for statistical outputs and research on the transitions and outcomes of people through education, the labour market, benefits, justice, health and safety, migration, and business data. The longitudinal aspect of the IDI covers an extended range of pathways and transitions information, to allow for policy evaluation and research analysis, and the production of statistical outputs. The IDI also contains surveys undertaken by Statistics NZ and other agencies, and includes the following data [69];

- Person and business tax data, student loans and allowances data - Inland Revenue

- Benefit data, student loans and allowances data Ministry of Social Development

- Secondary school achievement data, tertiary education data - Ministry of Education

- Sentencing data - Department of Corrections

- Injury data - Accident Compensation Corporation

- Migration and movements data - Ministry of Business, Innovation and Employment

- Departure and arrival cards - New Zealand Customs Service / Statistics NZ

- Household Labour Force Survey (HLFS) data Statistics NZ

- New Zealand Income Survey (NZIS) data - Statistics NZ

- Survey of Family Income and Employment (SoFIE) data - Statistics NZ

- Longitudinal Immigration Survey of New Zealand (LISNZ) data - Statistics NZ

- Longitudinal Business Database (LBD) data Statistics NZ.

\section{Emerging issues}

Kukutai [32] recommended that both descent and ethnicity data be collected. This enabled the collection of both ethnicity and descent at the same time, a practice adopted in the census in 1991 [49]. Without ethnicity, people for whom whakapapa is not part of their identity are unlikely to acknowledge the links between Māori and therefore a link with another Māori suggests that this is not only an unhealthy state as proposed by Durie [16,78], it is a form of cultural identity that is unlikely to correspond well with ethnic selfidentification.

The mixed collection of descent-based and ethnicity data appears to be acceptable for reporting on equity issues for health, education, and justice. Lack of a standard similar the HIOS ethnicity standard for descentbased data for government jurisdictions addressing inequality appears to allow room for incomplete data, in much the same way that incomplete or missing data compromised the health data prior to the health sector's adoption of the HISO Ethnicity Data Protocol [33]. Also the collection of ethnicity data outside the health sector does not appear to be governed by the HISO ethnicity data protocols [33] and without crossgovernment application of Ariā [63], may lead to bias arising from concealed undercounting. Misclassification can result in an undercount, and this was estimated in the Census Mortality Study to result in an underestimation of death registration, the authors commented,

The extent of this bias became apparent with the change to ethnicity recorded on the death registration form in September 1995 - the number of Māori deaths increased by $70 \%$ between 1994 and 1996 (90\% based on Māori ethnic group). In a paper recently published in this Journal we found that compared to death data, 29\% more 0-74 year old Māori had identified as sole-Māori on the 1991 census (or $46 \%$ for total Māori ethnic group) [59, p. 149]. 
Table 1 shows a hypothetical situation in metropolitan, urban and rural settings (the author adopted this from an idea presented by Prof. Joan Cunningham in 2002 in the Australian and New Zealand Journal of Public Health (vol 6, issue 6). Scenario one ('truth') shows an apparent enrollment of 15 percent of Indigenous students to achieve enrollment completeness is 100 percent, that is, all Indigenous enrollments are correctly classified for ethnicity.

In the second scenario (partial ethnicity completeness), the average level of reported school enrollment for Indigenous students has been reduced to 80 percent (urban), and the disparity by group has been increased, with enrollment completeness ranging from 65 percent (metropolitan) to 95 percent (rural). The ratio of the minima and maxima (metropolitan and rural) in this scenario is 1.46 , which indicates an almost 50 percent higher apparent Indigenous enrolment rate in rural compared with metropolitan, even though there is no difference in truth. This hypothetical situation illustrates how disparities in data collection by agencies who collect data (in this scenario the Ministry of Education, schools and tertiary education providers) could provide an inaccurate and potentially misleading analysis of Indigenous student enrolment. The data quality consequences of these inconsistencies for data linkage would be the increased administrative burden arising from additional data cleaning and testing. The impact of data inconsistencies on the education of Indigenous children may present as a bias against metropolitan because of an undercount of the variable critical to identifying Indigenous people.

\section{Conclusion}

The statistical concepts may be correct, but the measurement process may be imperfect $[79$, pp. $7-$ $8]$

The 2006 report of Commission on the Measurement of Economic Performance and Social Progress (the Commission) [79] recommended broadening the scope of the traditional indicators used to measure economic progress. It outlined a challenge for understanding statistics. The manner in which the data is collected must align with the underlying concepts or our decisions may be distorted. For example a rapidly increasing metric will describe more people worse off because the average is increasing, or inconsistent collection of ethnicity data that leads to false differences as illustrated in Table 1 and problematic data linkage. The
Commission's encouragement to consider new concepts has support from a longstanding Māori desire to engage in improving the quality of health and wellbeing of our nation, a nation that strives to achieve equity.

From his experience as a soldier, John Rangihau spoke of Māori commitment to Aotearoa-New Zealand, an expectation of citizenship and equity that compliments rights and expectations conferred with the Treaty of Waitangi. Mr Rangihau said,

This whole question of commitment was brought up before my eyes when I thought about the boys who made the supreme sacrifice, about the times the battalion had to go in, and the comradeship that grew out of fire between ourselves and other units of the New Zealand division; the way we teamed together when we were on leave; the way the Pakeha soldiers had a very good relationship with us. I was struck by the fact that this was the price for total citizenship in New Zealand. I felt I was totally committed to the land of my forebears and this meant for me another commitment to be accepted by the dominant group. I was to be accepted as part of the New Zealand scene, not as a noble savage or a descendant of noble savages, but as a person with rights and privileges I had fought for and bought [11, pp. 187-188].

The same expectation remains strong today, reflected in health priorities to address inequity that characterize the well-being of Māori today, a desire to see Māori perspectives applied to official statistics, and that data are robust. Two key aspects to the collection of high-quality health measurement data are the collection of consistent data and to minimize bias. Descent data, for example, when collected with iwi affiliation can result in undercounting. This is one of the many sources of bias that result in poor quality statistics, the result of incomplete data that lowered relative mortality rates that were actually increasing as reported by Blakely et al. in 2007 [57].

The statistics needed now and, in the future, to improve the well-being of Māori, and therefore our nation, are those which are underpinned by consistent application of ethnicity and descent protocols in the manner described by HISO 10001. We have learnt from the past that without consistent data standards and protocols, the utility of these statistics is seriously degraded making comparison fraught and conclusions open to criticism. The migration of these standards and protocols across administrative data is ad hoc and is likely to 
continue at an uneven pace unless this is made a performance issue regarding the implementation of Ariā [63] as a key whole of government objective.

We can strengthen communities through data and better measures by regaining their trust and learning from, and applying the lessons learnt from international efforts to improve Indigenous health measurement. Contributing to the international efforts is a challenge to Indigenous people whose perspectives, already tested in their own lands, can only be improved by international scrutiny and support.

\section{Acknowledgments}

The members of the International Group for Indigenous Health Measurement.

\section{References}

[1] Durie MH, Whaiora Maori health development, 1 ed. Whaiora Maori health development, 1994, Auckland: Oxford University Press.

[2] Durie M.H, Te uru mai o te motu -Millennium lecture series. [Whanau development and Maori survival, the challenge of time], in The proceedings of Te Hua-o-Te Whanau Conference. 1999, Ministry of Health: Palmerston North.

[3] Smith SP, Hawaiki: The Original Home of the Maori: With a Sketch of Polynesian History. Cambridge Library Collection - Anthropology, 2011, Cambridge: Cambridge University Press.

[4] Murray-McIntosh RP, et al., Testing migration patterns and estimating founding population size in Polynesia by using human mtDNA sequences, Proceedings of the National Academy of Sciences of the United States of America, 1998; 95(15): 9047-9052.

[5] Statistics New Zealand, Dates of New Zealand censuses since 1851. 2018; Available from: http://archive.stats.govt.nz/ Census/2013-census/info-about-the-census/intro-to-nzcensus/history/historic-census-dates.aspx.

[6] The Parliament of the United Kingdom, New Zealand Constitution Act (15 \& 16 Vict. c. 72$)$, 1852: London, England. p. 491-92.

[7] Mako C, Some Statistical Issues for Maori - Definitions and Application: A Keynote Address to Te Oru Rangahau Mäori Research and Development Conference, in The Proceedings of Te Oru Rangahau Maori Research and Development Conference, July 7-9, 1998, Te Pumanawa Hauora, Editor. 1999, Massey University: Palmeston North. p. 40-49.

[8] Statistics New Zealand, New Zealand literature review of Māori groupings. 201618 April 2016; Available from: http:// archive.stats.govt.nz/methods/classifications-and-stand ards/current-classifications-and-standards-review/ reviewstatistical-standard-iwi/nz-lit-review-maori-groupings.aspx.

[9] Rangihau J, Maoritanga: a lecture at Massey University at the time of the 1975 Maori Land March to Parliament, 1975, Massey University: Palmeston North. p. 16.
[10] Rangihau J, The Maori, in The New Zealanders, J. Seirs and J. Henderson, Editors. 1975, Millwood Press: Wellington. p. 117-20, 157-60.

[11] Rangihau J, Being Maori, in Te Ao Hurihuri - Aspects of Maoritanga, M. King, Editor. 1992, Reid Publishing: Auckland. p. 183-189.

[12] Walker R, Marae: a place to stand, in Te Ao Hurihuri - As pects of Maoritanga, M. King, Editor. 1992, Reid Publishing: Auckland. p. 15-27.

[13] Walker R, The Relevance of Maori Myth and Tradition, in Te Ao Hurihuri - Aspects of Maoritanga, M. King, Editor. 1992, Reid Publishing: Auckland. p. 170-182.

[14] Durie MH, Whanau development and Maori survival: The challenge of time-Te Uru Mai o te Motu - 1999 Millennium Address. in Te Hua o te Whanau: Whanau health and development conference. 1999. Te Putahi-a-Toi School of Maori Studies, Massey University, Palmerston North: Ministry of Health.

[15] Metge J, Changing whanau structures and practices. in Te Hua o te Whanau: Whanau health and development conference. 1999. Te Putahi-a-Toi School of Maori Studies, Massey University, Palmerston North: Ministry of Health.

[16] Durie MH, A Maori perspective of health, Social Science \& Medicine, 1985; 20(5):. 483-6.

[17] Davidson J, Maori Prehistory. The Journal of the Polynesian Society, 1983; 92(3): 291-308.

[18] Waldon JA, He Whakaturanga mo te Hauora Tamariki: A picture of child health, Social Science. 2008, Doctor of Philosophy Thesis (Maori Studies), Palmerston North: Massey University.

[19] Lowe DJ, Polynesian settlement of New Zealand and the impacts of volcanism on early Maori society: an update, in Australian and New Zealand 4thJoint Soils Conference, Massey University, Palmerston North (1-5 Dec. 2008), D.J. Lowe, Editor 2008, New Zealand Society of Soil Science.

[20] Salmond A, The Study of Traditional Maori Society: The State of the Art, The Journal of the Polynesian Society, 1983. 92(3): 309-332.

[21] Ulluwishewa R, et al., Indigenous knowledge for natural resource management: a comparative study of Māori in New Zealand and Dusun in Brunei Darussalam, GeoJournal, 2008. 73(4): 271-284.

[22] McFadgen BG, Maori Plaggen soils in New Zealand, their origin and properties. Journal of the Royal Society of New Zealand, 1980; 10(1): 3- 18 .

[23] House of Representatives, Maori Representation Act, 1867 , Government Printer: Wellington, New Zealand. p. 491-92.

[24] Ministry for Culture and Heritage, Māori and the vote. 2016 26 November 2016; Available from: https://nzhistory.govt.nz/ politics/maori-and-the-vote/setting-up-seats.

[25] Belich J, The New Zealand Wars and the Victorian Interpretation of Racial Conflict, 2015, Auckland, New Zealand: Auckland University Press. 400.

[26] Binney J, Te Upokokohua: The Curse of Confiscation on Te Urewera, in Raupatu: The Confiscation of Maori Land, 2009, Victoria University Press: Wellington. p. 222.

[27] Coleman A, Dixon S and Maré DC, Māori economic development - Glimpses from statistical sources, in Motu Working Paper 05-13, 2005, Motu Economic and Public Policy Research: Wellington.

[28] Statistics New Zealand, Review of the Measurement of Ethnicity-Background Paper, 2001, Statistics New Zealand: Wellington. p. 8.

[29] House of Representatives, Maori Affairs Amendment Act, 
1974, Government Printer: Wellington, New Zealand. p. 1708-50.

[30] Cormack D, Robson C, Classification and output of multiple ethnicities: issues for monitoring Māori health, 2010, Te Rōpū Rangahau Hauora a Eru Pōmare: Wellington.

[31] Callister P, et al., Measuring ethnicity in New Zealand: developing tools for health outcomes analysis. Ethnicity \& Health, 2007; 12(4): 299-320.

[32] Kukutai T, The Problem Of Defining An Ethnic Group For Public Policy: Who Is Maori And Why Does It Matter? Social Policy Journal of New Zealand, 2004; (23): 86-108.

[33] Ministry of Health, HISO 10001:2017 Ethnicity Data Protocols, 2017, Ministry of Health: Wellington.

[34] Orange C, The Treaty of Waitangi. 1987, Wellington: Allen \& Unwin New Zealand Limited.

[35] Te Puni Kokiri-Ministry of Maori Development, A Guide To The Principles Of The Treaty Of Waitangi As Expressed By The Courts \& The Waitangi Tribunal. 2001, Wellington: Te Puni Kokiri-Ministry of Maori Development.

[36] Cabinet Economic Growth and Infrastructure Committee, Census Transformation: A Promising Future, 2015, The Cabinet Office,: Wellington, New Zealand

[37] Statistics New Zealand, New Zealand Census of Population and Dwellings-Individual Form, [2013 2 January 2019]. Available from: https://unstats.un.org/unsd/demographic/sour ces/census/quest/NZL2013enIn.pdf.

[38] Statistics New Zealand, Iwi statistical standard: September 2017. 2017; Available from: http://archive.stats.govt.nz/meth ods/classifications-and-standards/classification-related-statsstandards/iwi.aspx.

[39] Tan L, Blakely T, Atkinson J, Ethnic counts on mortality and census data 2001-06: New Zealand census-mortality study update, The New Zealand Medical Journal (Online), 2010; 123(1320).

[40] Murchie E, Rapuora: Health and Maori Women, 1984, Wellington: The Maori Women's Welfare League/Te Ropu Wahine Maori Toko i Te Ora. 150 p.: ill., form, map, ports; 30 $\mathrm{cm}$.

[41] Durie MH, Te Hoe Nuku Roa Framework-a Maori Identity Measure, The Journal of the Polynesian Society, 1995; 104(4): 461-470.

[42] Te Hoe Nuku Roa, Te Hoe Nuku Roa Source Document: Baseline History, in Maori Profiles Research Project 1999: Palmerston North. p. iii, 146.

[43] Forster M, Te Hoe Nuku Roa: A Journey Towards Maori Centered Research, Ethnobotany Research \& Applications, 2003, pp. 47-53.

[44] Ministry of Maori Development, Oranga Kaumatua-the health and wellbeing of older Maori people, a report prepared for the Ministry of Health and Te Puni Kokiri by Te Pumanawa Hauora, Department of Maori Studies, Massey University, Palmerston North, 1997, Ministry of Maori Development Te Puni Kokiri: Wellington.

[45] New Zealand Government, Māori Language Act 1987, P.C. Office, Editor 1987, Parliamentary Counsel Office: Wellignton, New Zealand.

[46] Statistics New Zealand, Indicators Aotearoa New Zealand Ngā Tūtohu Aotearoa: Consultation, [2018 12 December 2018]; Available from: https://www.stats.govt.nz/consultati ons/indicators-aotearoa-new-zealand-nga-tutohu-aotearoaconsultation.

[47] Pomare EW, Hauora: Maori standards of health: A study of the 20-year period 1955-75, Special Report Series No. 7. 1980, Auckland: Medical Research Council of New Zealand.
[48] Cormack D, Making Ethnicity Data Count. BPJ, 2007, 44-46.

[49] Cormack D and Harris R, Issues in monitoring Māori health and ethnic disparities: an update, 2009, Te Rōpū Rangahau Hauora a Eru Pōmare: Wellington.

[50] Pomare EW and de Boer GM, Hauora: Maori Standards Health; a study of the years 1970-1984, Special report series 78, 1988, Wellington: Department of Health and Medical Research Council,

[51] Pomare E, Keefe-Ormsby V., Ormsby C, Pearce N, Reid P, Robson B, Watene-Haydon N, Hauora: Maori Standards of Health III, a study of the years 1970-1991. Hauora, Maori Standards of Health, ed. Te Ropu Rangahau Hauora a Eru Pomare. 1995, Wellington: Te Ropu Rangahau Hauora a Eru Pomare - Wellington School of Medicine,. 200.

[52] Ajwani S et al., Unlocking the numerator-denominator bias for the 1980s and 1990s. NZCMS Technical Report No. 4. 2002, Wellington: Department of Public Health, Wellington School of Medicine and Health Sciences, University of Otago.

[53] Ajwani S et al., Decades of Disparity: Ethnic mortality trends in New Zealand, 1981-1999, 2003, Ministry of Health and University of Otago: Wellington. p. IX, 119.

[54] Blakely T et al., Decades of Disparity II: Socioeconomic mortality trends in New Zealand, 1981-1999, 2005, Ministry of Health and University of Otago: Wellington. p. IX, 79.

[55] Ministry of Health and University of Otago, Decades of Disparity III: Ethnic and socioeconomic inequalities in mortality, New Zealand 1981-1999, 2006, Ministry of Health and University of Otago: Wellington. p. IX, 79.

[56] Ministry of Health and University of Otago, Ethnic and Socioeconomic Inequalities in Mortality, New Zealand 19811999, 2006, Ministry of Health and University of Otago: Wellington. p. xii, 79.

[57] Blakely T, Tobias M, Atkinson J, Yeh L-C, Huang K, Tracking Disparity: Trends in ethnic and socioeconomic inequalities in mortality,1981-2004, 2007, Ministry of Health: Wellington.

[58] Statistics New Zealand, Statistical Standard for Ethnicity 2005, 2005, Statistics New Zealand: Wellington.

[59] Blakely T, Robson B, Woodward A, Measuring Maori health status accurately - more needs doing, New Zealand Medical Journal, 2002. 115(1151): 149-150.

[60] Statistics New Zealand. Te Kupenga. 2013 [cited 2018; Available from: http://archive.stats.govt.nz/browse_for_stats/ people_and_communities/maori/te-kupenga.aspx.

[61] Statistics New Zealand. He Arotahi Tatauranga, 2014 [cited 2018; Available from: http://archive.stats.govt.nz/browse_for _stats/people_and_communities/maori/how-to-think-maoriinfo-needs/he-arotahi-tatauranga.aspx.

[62] Statistics New Zealand, Ethnicity. [2018, 13 December]; Available from: https://www.stats.govt.nz/topics/ethnicity.

[63] Statistics New Zealand, Ariā. [2019, 2 January]; Available from: https://www.stats.govt.nz/tools/aria.

[64] Te Mana Raraunga - Maori Data Sovereignty Network, Te Mana Raraunga - Māori Data Sovereignty Network Charter, 2016.

[65] Rangihau J, Foreward: Learning and tapu, in Te Ao Hurihuri - Aspects of Maoritanga, M. King, Editor. 1992, Reid Publishing: Auckland. p. 12-14.

[66] Tūhono. Tūhono. Tūhono Available from: https://www. tuhono.net/.

[67] Whitehead M, A typology of actions to tackle social inequalities in health, Journal of Epidemiology and Community Health, 2007; 61(6): 473.

[68] Robson B, Harris R, eds, Hauora: Māori Standards of Health 
IV. A study of the years 2000-2005, 2007, Te Rōpū Rangahau Hauora a Eru Pōmare, School of Medicine and Health Sciences, University of Otago: Wellington South.

[69] Statistics New Zealand, Linking methodology used by Statistics New Zealand in the Integrated Data Infrastructure project, 2014, Statistics New Zealand,: Wellington, New Zealand. p. 31.

[70] Kukutai T and Pawar S, A Socio-demographic Profile of Maori in Australia, NIDEA Working Papers, 2013(3): 87.

[71] Statistics New Zealand, Māori population estimates: At 30 June 2018. 2018; Available from: https://www.stats.govt.nz/ information-releases/maori-population-estimates-at-30-june2018

[72] Oranga Tamariki. Kids in care, 2018; Available from: https://www.msd.govt.nz/about-msd-and-our-work/publica tions-resources/statistics/cyf/kids-in-care.html.

[73] State Services Commission, A guide to using the Common Measurements Tool, 2011, State Services Commission, Wellington, New Zealand. p. 21

[74] New Zealand Police, Citizens' Satisfaction Survey - Full Report for 2017/18 Fiscal Year in Report Prepared by: Gravitas Research and Strategy Ltd Research, 2018. p. 187.

[75] Paterson R et al., He Ara Oranga : Report of the Government Inquiry into Mental Health and Addiction, 2018, The Government Inquiry into Mental Health and Addiction,: Wellingotn, New Zealand. p. 219.
[76] Ministry of Health, Moving Forward: The National Mental Health Plan for More and Better Services, 1997, Minustry of Health: Wellington, New Zealand. p. 305.

[77] Ministry of Health, Te Rau Hinengaro: The New Zealand Mental Health Survey, Mark A Oakley Browne, J Elisabeth Wells, and Kate M Scott, Editors. 2006, Minustry of Health: Wellington, New Zealand. p. 305.

[78] Durie M, Whanau, family and the promotion of health, in Annual Conference of The Public Health Association. 1994 Palmerston North: Public Health Association of New Zealand.

[79] Stiglitz J, Sen A, Fitoussi J, Report by the Commission on the Measurement of Economic Performance and Social Progress, 2009, Paris

[80] Reid G., Bycroft C, and Gleisner F, Comparison of ethnicity information in administrative data and the census, 2016, [2019]; Available from: http://archive.stats.govt.nz/ methods/research-papers/topss/comp-ethnic-admin-datacensus.aspx. 